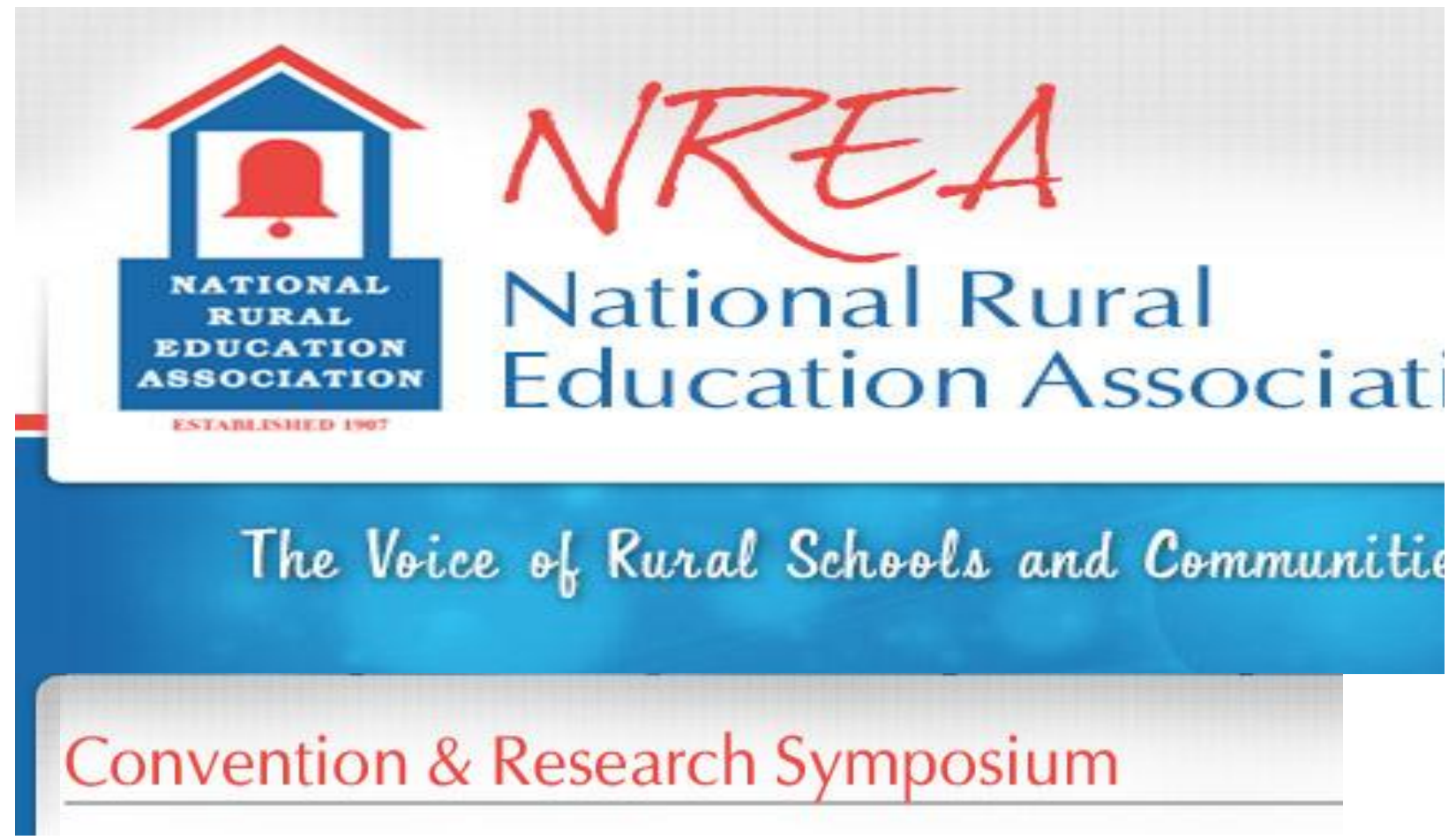

\title{
NREA Annual Convention
}

Save the Date! October 18-20, 2013 the 105th NREA convention and Research Symposium will be in Branson, Missouri. The theme of this year's meeting is "A New Generation of Learning in Rural Schools." The opening keynote speaker is John Nash from the University of Kentucky who will help us focus on the theme and stimulate our thinking. Please view our call for presentations at

http://www.nrea.net/viewpdf.cfm?filename=NREA_CallForPresentFlier_021519.pdf

We encourage you to submit a proposal. The research committee leadership has designed a variety of presentation formats. Registration is now open for the conference. An "early bird" rate is available until July 1.

\section{About Our Destination}

This year's convention will be at the Chateau on the Lake, Branson, Missouri. The autumn landscape in the Branson area explodes in an array of rich colors beginning in mid-September and lasting through November.

\section{Chateau on the Lake Hotel}

We invite you to experience Chateau on the Lake - Branson, Missouri's only AAA Four-Diamond Hotel, Spa \& Convention Center. 


\section{Call for Presentations}

\section{National Rural Education Association Annual Convention and Research Symposium October 18-20, 2013 \\ Branson, Missouri}

\section{Conference Theme: Next Generation Learning in Rural Schools}

The National Rural Education Association seeks presentation proposals from rural school teachers, administrators, researchers, and others interested in the future of rural education. This year's conference theme is Next Generation Learning in Rural Schools, and we are seeking presenters to share innovative practice or research related to the changing needs of rural students and the changing face of rural education. Areas of particular interest include: Rural School Innovations, Advancing Learning through Technology, Rural School Reform, Meeting Common Core Standards, Technology Applications for School Leaders, Redesigning Learning for 21st Century Skills, Rural School Partnerships, Policy Implications for Rural Schools, and Evaluating Effects of Rural Schools.

Three types of presentations are sought: Deadline June 15, 2013

Workshop: 30-minute presentations about current or promising practices in rural schools. Tell your story about innovations in teaching, learning, and leadership in rural schools.

Research Symposium: 15-20 minute presentations regarding research pertinent to rural schools.

Ignite Session: A cluster of four or five presentations on a similar topic or theme, where each presenter gives a five-minute Power Point presentation. Ignite sessions are intended to stimulate informal, lively discussions and spark interest and awareness of multiple yet similar topics.

\section{Contact Information}

John Hill, Executive Director

jehill@purdue.edu

Patti Chance, Co-Chair, Research Forum

pchance@mail.sdsu.edu

Susan Scherz, Co-Chair, Research Forum

sscherz@hansen.k12.id.us 